DOI: 10.20472/IAC.2018.036.035

MARGARITA PAVLOVA

The Education University of Hong Kong, Hong Kong

\title{
GREENING FINANCE INDUSTRY IN HONG KONG: THE ROLE OF PARTNERSHIP
}

\begin{abstract}
:
This paper adopted a case study approach to explore the role of partnerships between government, industry and education in transforming Hong Kong into a green finance hub. Findings from several interviews with the bank and finance companies in Hong Kong are presented, adding a new dimension to the existing literature in terms of providing new theoretical understanding to current practices with the intention of introducing environmental, social and governance (ESG) or sustainability related programs in the banking and finance industry of Hong Kong. The paper conceptualized existing partnership patterns in the finance industry with the education sector and government across the industry and explored their skills needs for the green economy.

The study reported in the paper highlighted that there is need to scale up green finance market development in promoting environmental sustainability in Hong Kong. This requires specific green finance developmental strategies from the government, finance and banking business community as well as the support of partnerships with universities. Our results revealed that vocational professional educational and training providers may not have a significant impact and neither will they share a significant role in greening the finance sector. A theoretical model adopted for the study (quintuple helix model) was used to illustrate the interaction and the flow of knowledge and innovation between different actors in support of sustainable development (Carayannis et. al., 2012). Based on this model, a framework to support effective partnerships for greening the finance industry is suggested. Such actions as the uptake of green bond and social responsible investment and improving disclosure standard of environmental, social and governance aspects in the field are proposed as important aspects for partnerships.
\end{abstract}

\section{Keywords:}

Partnership, green economic restructuring in Hong Kong; finance sector, human resource development; education

JEL Classification: O20, Q01, 125 